2019-11

Insights into interactions between

vanadium (V) bio-reduction and

pentachlorophenol dechlorination in

synthetic groundwater

Zhang, Baogang

http://hdl.handle.net/10026.1/17677

10.1016/j.cej.2019.121965

Chemical Engineering Journal

Elsevier BV

All content in PEARL is protected by copyright law. Author manuscripts are made available in accordance with publisher policies. Please cite only the published version using the details provided on the item record or document. In the absence of an open licence (e.g. Creative Commons), permissions for further reuse of content should be sought from the publisher or author. 


\title{
Insights into Interactions between Vanadium (V) Bio-reduction and Pentachlorophenol Dechlorination in Synthetic Groundwater
}

\author{
Yutong Cheng ${ }^{\mathrm{a}}$, Baogang Zhang ${ }^{\mathrm{a},}$, Jiaxin Shi ${ }^{\mathrm{a}}$, Xuan Xing ${ }^{\mathrm{b}}$, Yuling Zhu ${ }^{\mathrm{c}}$, Nan Xud \\ Jianxin Xia ${ }^{\mathrm{b}}$, Alistair G.L. Borthwick ${ }^{\mathrm{e}}$ \\ ${ }^{a}$ School of Water Resources and Environment, MOE Key Laboratory of Groundwater \\ Circulation and Environmental Evolution, China University of Geosciences (Beijing),
} Beijing 100083, P. R. China

${ }^{b}$ College of Life and Environmental Science, Minzu University of China, Beijing 100081, P. R. China

${ }^{c}$ College of Life Science, College of Chemistry and Chemical Engineering, Shaoxing University, Zhejiang 312000, P. R. China

${ }^{d}$ School of Environment and Energy, Peking University Shenzhen Graduate School, Shenzhen 518055, P. R. China

${ }^{e}$ School of Engineering, The University of Edinburgh, The King's Buildings, Edinburgh EH9 3JL, UK

* Corresponding author. Tel.: +86 108232 2281; Fax: +86 108232 1081. E-mail: baogangzhang@cugb.edu.cn (B. Zhang).

Declarations of interest: none 


\section{Abstract}

Aquifer co-contamination by vanadium $(\mathrm{V})$ and pentachlorophenol (PCP) involves complicated biogeochemical processes that remain poorly understood, particularly from the perspective of microbial metabolism. Batch experiment results demonstrated that V(V) and PCP could be competitively bio-reduced, with $96.0 \pm$ $1.8 \%$ of $\mathrm{V}(\mathrm{V})$ and $43.4 \pm 4.6 \%$ of $\mathrm{PCP}$ removed during $7 \mathrm{~d}$ operation. $\mathrm{V}(\mathrm{V})$ was bio-transformed to vanadium (IV), which could precipitate naturally under circumneutral conditions, facilitating the removal of up to $78.2 \pm 3.1 \%$ dissolved total V. The PCP reductive dechlorination products were mainly 2,4,6-trichlorophenol and 4-monochlorophenol with lower toxicity. High-throughput 16S rRNA gene sequencing indicated that Pseudomonas, Soehngenia, and Anaerolinea might be responsible for the two bio-transformations, with detected functional genes of nirS and $\operatorname{cpr} A$. Extracellular reduction by cytochrome $\mathrm{c}$ and intracellular conversion by nicotinamide adenine dinucleotide (NADH) occurred for both $\mathrm{V}(\mathrm{V})$ and PCP. Extracellular proteins in microbial-secreted extracellular polymeric substances (EPS) might also be involved in these enzymatic bioprocesses. EPS could protect microbial cells through $\mathrm{V}(\mathrm{V})$ binding by the chemically reactive carboxyl $\left(\mathrm{COO}^{-}\right)$, and hydroxyl $(-\mathrm{OH})$ groups. These findings elucidate the metabolic processes during anaerobic $\mathrm{V}(\mathrm{V})$ and PCP biotransformation, advance understanding of their biogeochemical fates, and provide a foundation on which to develop novel strategies for remediation of co-contaminated aquifers.

Keywords: Vanadium (V); Pentachlorophenol; Microbial reduction; Groundwater 


\section{Introduction}

The combined contamination of groundwater by heavy metals and organics has become a serious problem worldwide, threatening both the natural ecosystem and human health [1]. Vanadium, a redox-sensitive metal, widely occurring in the Earth's crust, is employed in metallurgy, manufacturing, and petroleum refining industries [2], and is an efficient catalyst in the selective catalytic reduction of nitrogen oxides in exhaust gases [3]. Dissolution of vanadium-rich rocks and anthropogenic activities lead to the presence of vanadium in groundwater [4,5]. For example, mining and smelting processes discharge vanadium into soil, after which vanadium can enter aquifers through infiltration [6]. Observed vanadium concentration in groundwater reached $0.77 \mathrm{mg} / \mathrm{L}$ at a site in Rifle, Colorado (USA), where smelting of vanadium ore was performed [7]. In Panzhihua, China, where vanadium titanomagnetite resource is abundant and intensive mining-smelting activities are conducted, an aquifer sample had a vanadium content of $0.208 \mathrm{mg} / \mathrm{L}$ [8]. These values far exceed the minimum reporting level $0.2 \mu \mathrm{g} / \mathrm{L}$ for vanadium proposed by the US Environmental Protection Agency [7,9]. Ingestion of vanadium, mainly as dust entering the lungs, can cause serious diseases in humans, such as pulmonary inflammation and tumors [10]. Vanadium can also adversely affect phosphate metabolism due to their structural similarity [11]. Toxicity of vanadium is positively related to its valence, with higher valences resulting in higher toxicities; vanadium $(\mathrm{V})(\mathrm{V}(\mathrm{V}))$ is the most harmful $[12,13]$

Pentachlorophenol (PCP) is widely used as a pesticide and disinfectant [14]. Due 
to its high toxicity (including probable carcinogenicity) and resistance to natural degradation, PCP has been listed as a priority pollutant by the US EPA [15]. PCP mainly collects in sediments and soils, but can also enter groundwater $[16,17]$. Although application of $\mathrm{PCP}$ in agriculture has been banned for several decades, $\mathrm{PCP}$ is still detected in groundwater due to its long-term persistence [18]. Moreover, agricultural activities can occur in and around vanadium mining and smelting areas, leading to co-occurrence of vanadium and PCP in groundwater [19]. Biogeochemical fates of vanadium and PCP in the geological environment include potential mobilization and redox reactions, which have been studied independently [6,20-22]. Nevertheless, little is known about their interactions in biogeochemical processes. In situ bioremediation at low-cost is a promising option for groundwater contaminated by vanadium and PCP [23-25]. In anaerobic conditions, the most toxic form of vanadium, $\mathrm{V}(\mathrm{V})$, can be bio-reduced to less toxic $\mathrm{V}(\mathrm{IV})$, which readily precipitates in the natural groundwater environment because V(IV) is insoluble at neutral $\mathrm{pH}$ [26]. Co-existing electron acceptors in aquifers, such as chromate and nitrate, are able to interact with $\mathrm{V}(\mathrm{V})$ during its bio-reduction, because such acceptors compete for electrons with V(V) [8,27]. Meanwhile, PCP is also a typical electron acceptor in bioprocesses, enabling anaerobically reductive dechlorination of PCP to occur in aquifers [28]. This provides a crucial pathway for degradation of PCP because aerobic transformation is relatively slow for highly chlorinated organic compounds [29]. Reductive dechlorination of PCP is also affected by reduction of other electron acceptors such as nitrate and sulfate [30,31]. Bio-reductions of V(V) 
and PCP have been intensively studied, using different types of electron donors $[7,13,25,32]$. Although V(V) bio-reduction and PCP reductive dechlorination can be associated, the interrelationships between $\mathrm{V}(\mathrm{V})$ and PCP co-occurring in aquifers during biotransformation processes are relatively unknown.

This paper describes an anaerobic incubation experiment conducted with $\mathrm{V}(\mathrm{V})$ and PCP present together in groundwater. The objectives are: (1) to understand the interactions between $\mathrm{V}(\mathrm{V})$ and $\mathrm{PCP}$ during biogeochemical processes in groundwater, and (2) to reveal primary mechanisms through identification of reduction products, analysis of microbial community dynamics, and examination of functional genes and pertinent enzymes. The results reveal associations between $\mathrm{V}(\mathrm{V})$ bio-reduction and PCP reductive dechlorination, and should be useful in developing techniques to remediate co-contaminated groundwater.

\section{Materials and methods}

\subsection{Experimental apparatus and solution condition}

All experiments were conducted in bioreactors constructed from $250 \mathrm{~mL}$ jars with silica gel stoppers as seals to maintain anaerobic conditions. The jars were covered in aluminum foil. Each bioreactor was inoculated with $50 \mathrm{~mL}$ microbial flocs obtained from a full-scale wastewater treatment facility, followed by a further $200 \mathrm{~mL}$ of synthetic groundwater [7]. The carbon source was ethanol $(75 \%, v / v)$ [33]. The $\mathrm{V}(\mathrm{V})$ source was $\mathrm{NaVO}_{3} \cdot 2 \mathrm{H}_{2} \mathrm{O}$. The bioreactors were designated as $\mathrm{B}-\mathrm{V}, \mathrm{B}-\mathrm{P}$, and 
B-V/P, according to whether they contained solutions with sole $\mathrm{V}(\mathrm{V})$, sole PCP, and both V(V) and PCP. A further abiotic reactor with sterilized inocula was employed as control, whose solution component was the same as B-V/P. All chemicals used in this study were purchased from Sinopharm Chemical Reagent Co., Ltd. (Beijing, China). The chemicals were analytical grade reagents and therefore used directly without further purification.

\subsection{Batch experiment procedure}

By refreshing the solutions every 3 days in an anaerobic environment (using a syringe to remove the exhausted solution and then replacing with fresh solution), all the bioreactors attained steady, repeatable performance after 3 months cultivation. Then, removals of $\mathrm{V}(\mathrm{V})$ and PCP were determined over three consecutive operation cycles ( $7 \mathrm{~d}$ for each cycle) by analyzing samples taken at prescribed time intervals. Initial conditions were as follows: $0.50 \mathrm{~mL} / \mathrm{L}$ ethanol dosage in all reactors; $10 \mathrm{mg} / \mathrm{L}$ $\mathrm{V}(\mathrm{V})$ in $\mathrm{B}-\mathrm{V}$; $10 \mathrm{mg} / \mathrm{L}$ PCP in B-P; and both $10 \mathrm{mg} / \mathrm{L} \mathrm{V}(\mathrm{V})$ and $10 \mathrm{mg} / \mathrm{L} \mathrm{PCP}$ in B-V/P. Corresponding reduction products were monitored in B-V/P. Microbial community structures were analyzed using high throughput sequencing. Functional genes and pertinent enzymes were also quantified. A subsequent parameter study examined the influences of the following key factors in B-V/P: initial V(V) concentration $(5 \mathrm{mg} / \mathrm{L}, 10 \mathrm{mg} / \mathrm{L}, 15 \mathrm{mg} / \mathrm{L}$ and $20 \mathrm{mg} / \mathrm{L})$; and initial ethanol dosage $(0.25 \mathrm{~mL} / \mathrm{L}, 0.35 \mathrm{~mL} / \mathrm{L}, 0.50 \mathrm{~mL} / \mathrm{L}, 0.60 \mathrm{~mL} / \mathrm{L})$. All trials were performed in triplicate at room temperature $\left(22 \pm 2{ }^{\circ} \mathrm{C}\right)$, with mean and standard deviation calculated [Is the standard deviation calculated from just three numbers? - if so, the 
sample size may be too small!].

\subsection{Physicochemical analysis}

Prior to analysis, a $0.22-\mu \mathrm{m}$ filter was used to pretreat all water samples. V(V) measurement was performed spectrophotometrically [8]. Dissolved total V was determined by inductively coupled plasma mass spectrometry (Thermo Fisher X series, Germany). Deposits were separated from the biomass through ultrasonication, and collected by centrifugation at $8000 \mathrm{rpm}$. X-ray photoelectron spectroscopy (XPS) (Axis Ultra, Kratos, UK) was used to study the valences of the ingredients of the deposits. PCP concentration was measured by high-performance liquid chromatography (LC-10A, Shimadzu, Japan), and PCP transformation products were identified by gas chromatograph-mass spectrometry (Trace GC-DSQ, Thermo Fisher, USA), following standard procedure [34,35]. Total organic carbon (TOC) was measured using a total carbon analyzer (TOC-5000, Shimadzu, Japan). pH was monitored by HI 3221 pH/ORP meter (Hanna Instruments Inc., USA).

\subsection{Molecular biology analysis}

The total genomic DNA of inocula, biomass in B-V, B-P, and B-V/P were extracted, using the FastDNA ${ }^{\circledR}$ SPIN Kit for Soil (Qiagen, USA) following manufacturer's instructions. PCR (GeneAmp ${ }^{\circledR}$ 9700, ABI, USA) was employed to pool and amplify the above DNA, with commonly used primers $338 \mathrm{~F}$ (ACTCCTACGGGAGGCAGCAG) and 806R (GGACTACHVGGGTWTCTAAT) [32]. The mixture of amplicons was first purified and quantified, using a MiSeq 
sequencing platform (Illumina, USA) for high-throughput 16S rRNA gene sequencing. Obtained sequences were submitted to the NCBI Sequence Read Archive with accession number SRP132559. RDP Classifier against silva (SSU115) 16S rRNA database was used to obtain the phylogenetic affiliations of representative sequences, following existing studies $[8,36,37]$.

Quantitative PCR (qPCR) was performed to quantify functional genes using a real-time quantitative PCR detection system (ABI 7500, Applied Biosystems, USA) following accepted procedures $[38,39]$. The primer sets were as follows: napA V17F (5'-TGGACVATGGGYTTYAAYC-3') and napA 4R (5'-ACYTCRCGHGCVGTRCCRCA-3') for the napA gene; nirScd3aF (5'-GT(C/G)AACGT(C/G)AAGGA(A/G)AC(C/G)GG-3') and nirSR3cd (5'-GA(C/G)TTCGG(A/G)TG(C/G)GTCTTGA-3') for the nirS gene; and f4-m3-g1 (5'-CRGAACYCTYGGYTAYAWTGC-3') and r3-m3g1 (5'-CCATAVCCRAAGATATCATC-3') for the cprA gene. Cytochrome c on cell surfaces, intracellular nicotinamide adenine dinucleotide (NADH), and extracellular polymeric substances (EPS) including extracellular proteins (PN), polysaccharides (PS), and humic-like substances (HS) were extracted, quantified, and then normalized to volatile suspended solids (VSS) [37,40,41]. (It should be noted that EPS are secreted through microbial metabolism and participate in metals reduction via extracellular enzymes or redox sensitive matter, besides binding metals by functional groups.) Fourier transform infrared (FTIR) spectrum for EPS was measured using a spectrometer (Nicolet 6700, Thermo, USA) to verify functional groups. 


\section{Results and discussion}

\subsection{Synchronous bio-reductions of $V(V)$ and PCP}

Concentrations of $\mathrm{V}(\mathrm{V})$ and $\mathrm{PCP}$ gradually decreased in $\mathrm{B}-\mathrm{V} / \mathrm{P}$ over the three consecutive operation cycles considered (Fig. 1), demonstrating synchronous removal of $\mathrm{V}(\mathrm{V})$ and PCP during the bioprocess. In an operational cycle $(7 \mathrm{~d})$, the removal efficiencies of $\mathrm{V}(\mathrm{V})$ and $\mathrm{PCP}$ in $\mathrm{B}-\mathrm{V} / \mathrm{P}$ were $96.0 \pm 1.8 \%$ and $43.4 \pm 4.6 \%$; the corresponding average removal rates of $\mathrm{V}(\mathrm{V})$ and $\mathrm{PCP}$ were $1.37 \pm 0.03 \mathrm{mg} / \mathrm{L} \cdot \mathrm{d}$ and $0.61 \pm 0.01 \mathrm{mg} / \mathrm{L} \cdot \mathrm{d}$. This suggests that groundwater co-contaminated by metal ions and organics, in this case $\mathrm{V}(\mathrm{V})$ and PCP, could be successfully remediated by an anaerobic bio-technique. The $\mathrm{V}(\mathrm{V})$ removal efficiency in $\mathrm{B}-\mathrm{V} / \mathrm{P}$ was lower than that in the B-V bioreactor (treating solely $\mathrm{V}(\mathrm{V})$ ), where the removal efficiency reached $76 \%$ in $12 \mathrm{~h}$ operation with initial $\mathrm{V}(\mathrm{V})$ concentration at $75 \mathrm{mg} / \mathrm{L}$ [42]; this was due to the strong toxicity of co-existing PCP in B-V/P. However, PCP removal efficiency in B-V/P was comparable to previously reported results, where approximately $50 \%$ of PCP was removed after 10 days by microbes in soil with initial PCP concentration of $8 \mathrm{mg} / \mathrm{L}$ [43]. In reported contaminated aquifers, PCP concentrations (around $0.1 \mathrm{mg} / \mathrm{L}$ ) were much lower than V(V) $(9.66 \mathrm{mg} / \mathrm{L})[44,45]$, therefore, both $\mathrm{V}(\mathrm{V})$ and PCP could be efficiently removed by the proposed bioprocess.

Gradual removals of V(V) in B-V and PCP in B-P were also detected (Fig. 1a), with reduction efficiencies of $97.2 \pm 4.2 \%$ and $49.3 \pm 1.5 \%$ and removal rates of 1.94 
$\pm 0.04 \mathrm{mg} / \mathrm{L} \cdot \mathrm{d}$ and $0.70 \pm 0.02 \mathrm{mg} / \mathrm{L} \cdot \mathrm{d}$ respectively. Unlike inhibited $\mathrm{V}(\mathrm{V})$ and enhanced $\mathrm{Cr}(\mathrm{VI})$ detoxifications in an analogous bio-system for joint removals of $\mathrm{Cr}(\mathrm{VI})$ and $\mathrm{V}(\mathrm{V})$ [27], both $\mathrm{V}(\mathrm{V})$ and PCP removals were suppressed in B-V/P compared to B-V and B-P. This indicated a competitive relationship between $\mathrm{V}(\mathrm{V})$ and PCP during their bio-reduction. Furthermore, V(V) was removed more quickly than PCP. Although the standard reduction potential of $\mathrm{VO}_{2}^{+} / \mathrm{VO}^{2+}(0.991 \mathrm{~V})$ is close to that of PCP $(0.990 \mathrm{~V})$ [46], PCP is much more biotoxic than $\mathrm{V}(\mathrm{V})$ and so the microbes were accordingly less able to adapt [47]. After 7 days, hardly any further removals of V (V) and PCP occurred in the sterilized reactor (Fig. S1, Supporting Information), indicating that living microbes played crucial roles in the $\mathrm{V}(\mathrm{V})$ and $\mathrm{PCP}$ reductive biotransformation processes as biocatalysts, and that the inocula made negligible contribution to adsorption.

\subsection{Identification of reaction products}

During operation, blue precipitates appeared at the bottom of the B-V/P bioreactor (Fig. S2, Supporting Information) accompanied by a gradually decreasing quantity of dissolved total V (Fig. 2a). After $7 \mathrm{~d}$ operation, the removal efficiency of dissolved total $\mathrm{V}$ in $\mathrm{B}-\mathrm{V} / \mathrm{P}$ was $78.2 \pm 3.1 \%$, indicating that the $\mathrm{V}(\mathrm{V})$ reduction products had precipitated naturally. (Similar phenomena have also been reported for other microbial $\mathrm{V}(\mathrm{V})$ reduction systems $[7,9]$.) The precipitates were collected and analyzed by XPS (Fig. 2b). The peak at $515.9 \mathrm{eV}$ in the $\mathrm{V} 2 \mathrm{p}$ high resolution spectrum corresponds to $\mathrm{V}(\mathrm{IV})$, indicating that $\mathrm{V}(\mathrm{IV})$ was the main reduction product of $\mathrm{V}(\mathrm{V})$ through microbial transformation [48,49], consistent with previous findings [9]. The 
produced V(IV) is readily re-oxidized in air [50], leading to the observed peaks corresponding to $\mathrm{V}(\mathrm{V})$.

Intermediates including 2,4,6-trichlorophenol (2,4,6-TCP), 2,4-dichlorophenol (2,4-DCP), 4-monochlorophenol (4-MCP), and phenol were detected during the PCP removal process (Fig. 2c). All these degradation intermediates were also observed in a previous study of microbial dechlorination of PCP [51]. Linked to the gradual decrease in PCP concentration, the appearance of these intermediates implies that the microbial transformation processes underwent reductive dechlorination reactions [52]. The initial gradual increase in concentration of the intermediates indicates that PCP reductive dechlorination occurred through several ways under anaerobic conditions, given the intermediates were produced at same time; candidate mechanisms include a single-electron transfer, an organocobalt adduct, and a halogen-cobalt bond [53]. Then concentrations of 2,4,6-TCP and 2,4-DCP decreased, implying that the PCP intermediates themselves could also be further dechlorinated [54]. After complete dechlorination, the intermediates could be mineralized to carbon dioxide for detoxification by microbes under aerobic/anaerobic conditions [17].

The concentration of TOC also gradually decreased with reaction time (Fig. 2d), implying the added ethanol was consumed as the carbon source by microorganisms as they reduced $\mathrm{V}(\mathrm{V})$ and PCP. Interestingly, phenol concentration deceased in the later stages (Fig. 2c), consistent with previous studies [43], showing that chlorophenols were ring-cleaved, and phenol acted as a supplementary carbon source for heterotrophs to realize partial mineralization of PCP through co-metabolism [55]. 
Solution $\mathrm{pH}$ increased slightly within the $7 \mathrm{~d}$ operation, which might be induced by proton consumption in microbial $\mathrm{V}(\mathrm{V})$ reduction and $\mathrm{PCP}$ anaerobic dechlorination $[56]$.

\subsection{Influences of initial $\mathrm{V}(\mathrm{V})$ concentration and ethanol dosage}

$\mathrm{V}(\mathrm{V})$ removal efficiency was affected by initial $\mathrm{V}(\mathrm{V})$ concentration as the total electron acceptors and the ratio of $\mathrm{V}(\mathrm{V})$ and PCP varied under different initial $\mathrm{V}(\mathrm{V})$ concentrations. Complete V(V) removal occurred for initial concentrations below 10 $\mathrm{mg} / \mathrm{L}$ within the 7-d operation period, whereas $\mathrm{V}(\mathrm{V})$ reduction efficiency decreased to $83.1 \pm 4.6 \%$ for an initial concentration of $20 \mathrm{mg} / \mathrm{L}$ (Fig. 3a). Nevertheless, the average $\mathrm{V}(\mathrm{V})$ removal rate improved from $0.92 \pm 0.02 \mathrm{mg} / \mathrm{L} \cdot \mathrm{d}$ to $2.61 \pm 0.02 \mathrm{mg} / \mathrm{L} \cdot \mathrm{d}$ as the initial $\mathrm{V}(\mathrm{V})$ concentration was increased from $5 \mathrm{mg} / \mathrm{L}$ to $20 \mathrm{mg} / \mathrm{L}$. Similar trends were observed for PCP (Fig. 3b). PCP removal efficiency decreased by $40.1 \pm$ $1.7 \%$ and its removal rate decreased from $0.94 \pm 0.02 \mathrm{mg} / \mathrm{L} \cdot \mathrm{d}$ to $0.37 \pm 0.01 \mathrm{mg} / \mathrm{L} \cdot \mathrm{d}$ as the initial $\mathrm{V}(\mathrm{V})$ concentration increased from $5 \mathrm{mg} / \mathrm{L}$ to $20 \mathrm{mg} / \mathrm{L}$. This implies that the proposed system could remove $\mathrm{V}(\mathrm{V})$ efficiently, even when encountering higher initial concentrations, and that reduction of $\mathrm{V}(\mathrm{V})$ takes precedence over PCP under the conditions examined. Initial contaminant concentration had a similar effect on the removal of contaminants when microbial vanadate and chromate reductions were implemented in isolation of each other [27].

Improved $\mathrm{V}(\mathrm{V})$ and PCP removal efficiencies were achieved by increasing the initial ethanol dosage (Fig. 3c, Fig. 3d), owing to the bioavailability of carbon source which significantly affects bio-reduction processes [13]. The V(V) reduction 
efficiency increased from $82.3 \pm 1.6 \%$ to $99.1 \pm 3.3 \%$ as the initial ethanol dosage was raised from $0.25 \mathrm{~mL} / \mathrm{L}$ to $0.60 \mathrm{~mL} / \mathrm{L}$, whereas the $\mathrm{PCP}$ efficiency meanwhile increased from $11.3 \pm 0.7 \%$ to $56.5 \pm 1.1 \%$. V(V) was bio-reduced much faster than PCP. The average removal rates of V(V) and PCP increased by $0.52 \pm 0.02 \mathrm{mg} / \mathrm{L} \cdot \mathrm{d}$ and $0.53 \pm 0.02 \mathrm{mg} / \mathrm{L} \cdot \mathrm{d}$. Further $\mathrm{V}(\mathrm{V})$ with lower toxicity was respired by microorganisms and inhibition of PCP removal was more evident when carbon sources were limited. About $330 \mathrm{mg} / \mathrm{L}$ organics in terms of COD were required to reduce $1 \mathrm{mM} \mathrm{V(V),} \mathrm{[57].} \mathrm{With} \mathrm{sufficient} \mathrm{carbon} \mathrm{sources} \mathrm{supporting} \mathrm{increased}$ microbial activity, then more PCP of stronger toxicity could be transformed.

\subsection{Microbial community evolutions}

Microbial richness decreased with addition of V(V) and/or PCP, as reflected by the rarefaction curves generated using Mothur (version v.1.30.1) (Fig. S3, Supporting Information). The Ace and Chaol richness indexes indicate that a more obvious decrease in richness took place in B-P than $\mathrm{B}-\mathrm{V}$ due to the higher toxicity of PCP than V(V) (Table S1, Supporting Information). Microbial richness further decreased in B-V/P because of superimposed toxicity. However, the Simpson and Shannon diversity indexes indicated that the microbial community became more diverse in B-P than that in $\mathrm{B}-\mathrm{V}$, whereas $\mathrm{B}-\mathrm{V} / \mathrm{P}$ possessed the lowest microbial diversity. The microbial richness and diversity reflected by these indexes were also lower than obtained in $\mathrm{V}(\mathrm{V})$ and $\mathrm{Cr}(\mathrm{VI})$ co-existing systems [58], due to the high toxicity of PCP.

Microbial consortium at phylum level evolved (Fig. 4a). Spirochaetae and Proteobacteria were significantly enriched in B-V. Chloroflexi accumulated in 
abundance in B-P. When V(V) and PCP were simultaneously introduced, Bateroidetes became predominant and the relative abundance of Firmicutes also increased, implying that these microbes could tolerate and/or detoxify V(V) and PCP. Functional species involved in $\mathrm{V}(\mathrm{V})$ and $\mathrm{PCP}$ reductions with energy owing to the anaerobic oxidation of organics were specified at genus level (Fig. 4b). In B-V, Pseudomonas was able to employ $\mathrm{V}(\mathrm{V})$ as the terminal electron acceptor in anaerobic respiration, enabling $\mathrm{V}(\mathrm{V})$ to be reduced and detoxified [59] Its enrichment is likely to have promoted V(VI) removal in B-V. A previous study has shown that accumulation of Azotobacter could reduce Cr(VI) with the aid of EPS [60]. Hence, EPS could also participate similarly in $\mathrm{V}(\mathrm{V})$ bio-reduction. Turning to B-P, enriched Comamonas genus has active electron transfer abilities [61], and so was selected for nitrobenzene and nitrate reductions [62]. Enriched Comamonas could also play a function in PCP removal whereby reductive dechlorination occurred through multiple electron transfer processes [63]. Newly appeared Longilinea is an obligately anaerobic syntrophic bacterium known to ferment carbohydrates to acetate and $\mathrm{H}_{2}$, and so could be utilised by microbes for PCP dechlorination [64]. Enriched Acinetobacter is capable of degrading phenol [65], and so could be propitious in the partial mineralization of PCP under anaerobic conditions. In B-V/P, Pseudomonas could contribute to both $\mathrm{V}(\mathrm{V})$ and PCP removals, noting its ability to degrade chlorophenol [66]. Soehngenia, which appeared in abundance, is an anaerobic benzaldehyde-converting microbe that can reduce thiosulfate and ferment sugars [67]. Anaerolinea is a chemoorganotrophic, presumptive fermenter capable of oxidizing $\mathrm{N}$-acetylglucosamine and reducing nitrate 
[68]. Nitrate and sulfate reducers are frequently involved in V(V) and PCP bio-reductions [8,34], thus simultaneous bio-reductions in V(V) and PCP could be partially attributed to the presence of Soehngenia and Anaerolinea with alternative electron acceptors.

\subsection{Genetic abundance, enzymatic concentration and metabolic pathways}

Fig. 5a is a histogram showing the measured quantities of functional genes which might possibly contribute to the $\mathrm{V}(\mathrm{V})$ and PCP removals. The nitrate reductase gene napA and nitrite reductase gene nirS are found in $\mathrm{B}-\mathrm{V}$. It has previously been observed that nitrate/nitrite reductases could be involved in V(V) reduction [69].

Detection of these two genes in B-V further supports this finding. In B-P, PCP removal was probably related to the occurrence of chlorophenol reductive dehalogenase gene $\operatorname{cpr} A$ [39]. Owing to the co-existence of $\mathrm{V}(\mathrm{V})$ and PCP, nirS was upregulated $(p<0.001)$, with the disappearance of napA and slight decrease in cprA $(p<0.05)$ resulting from interactions between the two contaminants.

Fig. $5 \mathrm{~b}$ shows measured quantities of pertinent enzymes participating in $\mathrm{V}(\mathrm{V})$ and PCP bio-transformations. The level of cytochrome $\mathrm{c}$ in $\mathrm{B}-\mathrm{V}$ is comparable to that in B-P. Cytochrome $\mathrm{c}$ is the key protein responsible for extracellular electron transfer to reduce $\mathrm{V}(\mathrm{V})$ and $\mathrm{PCP}[27,63]$. Additional synthesis of cytochrome $\mathrm{c}$ in $\mathrm{B}-\mathrm{V}$ was probably responsible for faster $\mathrm{V}(\mathrm{V})$ removal. NADH is the essential enzyme required for cellular catabolic activity to break down macromolecules; its involvement in intracellular $\mathrm{Au}(\mathrm{III})$ reduction to $\mathrm{Au}(0)$ has been reported in the literature [70]. Detection of cytochrome c and NADH enzymes implied V(V) and PCP were reduced 
both extracellularly and intracellularly because a mixed culture was employed.

Extracellular reduction might predominate at higher concentrations of cytochrome c. Intracellular reduction was further confirmed by the over-expressions of genes encoding $\mathrm{ABC}$ transporters (Fig. S4, Supporting Information). ABC transporters support cellular defense systems by transporting and detoxifying toxic substances passing through cell membranes, and then releasing them from the cells [71]. As the detoxification process occurs in cells with $\mathrm{ABC}$ transporters, thus intracellular reduction is confirmed. Higher concentrations of cytochrome $\mathrm{c}$ and NADH enzymes were found in $\mathrm{B}-\mathrm{V}$ than $\mathrm{B}-\mathrm{P}$, resulting in faster $\mathrm{V}(\mathrm{V})$ reduction in $\mathrm{B}-\mathrm{V}$. Concentrations of both cytochrome $\mathrm{c}$ and NADH further increased in B-V/P, indicating that synchronous $\mathrm{V}(\mathrm{V})$ and PCP reductions had occurred.

EPS were often secreted to protect microbial cells during the intrusion of toxicants. Fig. 6a presents a histogram of the constituents of EPS. In B-V, PN accounted for the largest part of EPS, followed by HS and PS. Enzymes in PN could have contributed to the catalytic reduction of $\mathrm{V}(\mathrm{V})$, noting its reported ability to reduce $\mathrm{Cr}(\mathrm{VI})$ [72]. Furthermore, the presence of HS confirmed its possible role in $\mathrm{V}(\mathrm{V})$ binding at neutral $\mathrm{pH}$ as demonstrated previously [73], where HS was found to help protect cells so that they could maintain key metabolisms. Carboxyl $\left(\mathrm{COO}^{-}\right)$and hydroxyl (-OH) groups were identified in the FTIR spectrum (Fig. 6b), providing supplementary evidence, given that such groups could chelate with metal ions to form complexes [74]. The appearance of a C-N band further confirmed the presence of proteins in EPS. Although EPS also participated in PCP removal [75], concentrations 
of the three constituents of EPS were lower in B-P than in B-V (Fig. 6a), due to inhibition of microbial activity induced by highly-toxic PCP. However, their concentrations further increased in B-P/V, probably because of antagonism between the two pollutants.

\subsection{Proposed mechanisms and environmental implications}

Fig. 7 displays proposed mechanisms for the interrelationship between $\mathrm{V}(\mathrm{V})$ bio-reduction and PCP dechlorination, noting the reduction products, microbial communities, functional genes, and pertinent enzymes. Contaminant removal processes were inhibited due to competition of electrons from ethanol oxidation, though they could be removed in parallel. Pseudomonas, Soehngenia, and Anaerolinea were believed to play crucial roles in $\mathrm{V}(\mathrm{V})$ and PCP reductive removals [66-68], when in co-existence. Functional genes regulated these processes, with nirS for $\mathrm{V}(\mathrm{V})$ bio-reduction and cprA for PCP dechlorination, respectively $[39,69]$. Both $\mathrm{V}(\mathrm{V})$ and PCP appeared to be bio-transformed intracellularly by NADH and extracellularly by cytochrome c $[27,70]$. This implies that the two reported pathways for microbial $\mathrm{V}(\mathrm{V})$ reduction, i.e. direct respiration of $\mathrm{V}(\mathrm{V})$ through electron transfer and detoxification of $\mathrm{V}(\mathrm{V})$ by binding it to other reductases, took place simultaneously [57]. Catalytic cleavage of the $\mathrm{C}-\mathrm{Cl}$ bond in PCP was achieved by the terminal chlorophenol reductive dehalogenase in the chlorophenol respiratory chain encoded by the cprA gene [76]. Electrons from NADH might enter this respiratory chain via NADH dehydrogenase [58]. Figure 7 also highlights the functions of EPS secreted by microbes. Besides catalytic reductions in V(V) and PCP by enzymes in 
PN, EPS could also directly bind toxicants through functional groups such as $\mathrm{COO}^{-}$ and - $\mathrm{OH}$ for microbes to tackle toxic substances [37]. $\mathrm{V}(\mathrm{V})$ was bio-transformed to ready precipitated $\mathrm{V}(\mathrm{IV})$, while PCP was converted to less toxic organic compounds, both of which would alleviate co-contamination caused by V(V) and PCP in an aquifer. Faster $\mathrm{V}(\mathrm{V})$ removal was found to occur than for PCP, probably due to higher toxicity of PCP, although they possess similar standard reduction potentials [46]. This trend differed from bio-reduction of $\mathrm{V}(\mathrm{V})$ and $\mathrm{Cr}(\mathrm{VI})$, which depended mainly on redox potentials [57].

This work revealed the competitive interactions between $\mathrm{V}(\mathrm{V})$ reduction and PCP dechlorination. The results imply that $\mathrm{V}(\mathrm{V})$ and PCP would be competitively bio-reduced in anaerobic natural aquifers. Based on the bioprocess identified in the present paper, remediation strategies could be proposed for $\mathrm{V}(\mathrm{V})$ and PCP co-contaminated groundwater. Principles obtained from a parameter study examining the effect of different operating factors could be used to optimize the proposed biosystem. In practical applications, other operational parameters, such as the hydraulic retention time, would require careful selection. Noting that PCP was bio-reduced more slowly than $\mathrm{V}(\mathrm{V})$, intensification methods such as multistage bioprocesses and their combination with chemical reduction by zerovalent iron could be employed to enhance PCP dechlorination [77]. Although the products from PCP reductive dechlorination are less toxic, they are nevertheless environmental contaminants. Therefore, other means, such as aerobic degradation and advanced oxidation processes, should also be considered for the complete mineralization of PCP 
$[78,79]$.

\section{Conclusions}

In this work, biogeochemical processes of $\mathrm{V}(\mathrm{V})$ and $\mathrm{PCP}$ occurring concurrently in synthetic groundwater were investigated. It was found that $\mathrm{V}(\mathrm{V})$ and PCP can be competitively bio-reduced under anaerobic conditions, with removal efficiencies in 7 d operation of $96.0 \pm 1.8 \%$ obtained for $\mathrm{V}(\mathrm{V})$ and $43.4 \pm 4.6 \%$ for PCP, respectively. $\mathrm{V}(\mathrm{V})$ was bio-transformed to insoluble and less toxic $\mathrm{V}(\mathrm{IV})$, achieving $78.2 \pm 3.1 \%$ removal of dissolved total V. PCP reductive dechlorination products such as 2,4,6-trichlorophenol and 4-monochlorophenol with lower toxicity were detected. Soehngenia, and Anaerolinea contributed to the bio-transformations. Both extracellular reduction by cytochrome $\mathrm{c}$ and intracellular conversion by NADH occurred. Possible roles of EPS with detected components and functional groups such as $\mathrm{COO}^{-}$and $-\mathrm{OH}$ were examined. The findings provide insight into the interaction of $\mathrm{V}(\mathrm{V})$ and PCP co-contaminants, through which better techniques could be devised to remove such co-contaminants from groundwater. It is recommended that future work be conducted using a continuous column in order to optimize operation conditions for practical application.

\section{Acknowledgements}

This research work was supported by Beijing Natural Science Foundation (No. 
8192040) and Beijing Nova Program (No. Z171100001117082).

\section{References}

[1] G.X. Huang, M. Zhang, C.Y. Liu, L.P. Li, Z.Y. Chen, Heavy metal(loid)s and organic contaminants in groundwater in the Pearl River Delta that has undergone three decades of urbanization and industrialization: Distributions, sources, and driving forces, Sci. Total Environ, 635 (2018) 913-925.

[2] R. Zhang, T. Leiviskä, J. Tanskanen, B. Gao, Q. Yue, Utilization of ferric groundwater treatment residuals for inorganic-organic hybrid biosorbent preparation and its use for vanadium removal, Che. Eng. J. 361, (2019) 680-689.

[3] J. Xu, G. Chen, F. Guo, J. Xie, Development of wide-temperature vanadium-based catalysts for selective catalytic reducing of NOx with ammonia: Review, Chem. Eng. J. 353, (2018) 507-518.

[4] M.D.P. Alvarez, E. Carol, Geochemical occurrence of arsenic, vanadium and fluoride in groundwater of Patagonia, Argentina: Sources and mobilization processes, J. S. Am. Earth Sci. 89, (2019) 1-9.

[5] Y.F. Jiang, B.G. Zhang, C. He, J.X. Shi, A.G.L. Borthwick, X.Y. Huang, Synchronous microbial vanadium (V) reduction and denitrification in groundwater using hydrogen as the sole electron donor, Water Res. 141 (2018) 289-296.

[6] B. Zhang, S. Wang, M. Diao, J. Fu, M. Xie, J. Shi, Z. Liu, Y. Jiang, X. Cao, A.G.L. Borthwick, Microbial community responses to vanadium distributions in mining geological environments and bioremediation assessment, J. Geophys. Res.: 
Biogeo. (2019) in press.

[7] B.G. Zhang, R. Qiu, L. Lu, X. Chen, C. He, J. Lu, Z.J. Ren, Autotrophic vanadium $(\mathrm{V})$ bioreduction in groundwater by elemental sulfur and zerovalent iron, Environ. Sci. Technol. 52 (2018) 7434-7442.

[8] H. Liu, B.G. Zhang, H.Y. Yuan, Y.T. Cheng, S. Wang, Z. He, Microbial reduction of vanadium (V) in groundwater: Interactions with coexisting common electron acceptors and analysis of microbial community, Environ. Pollut. 231 (2017) 1362-1369.

[9] A.P. Yelton, K.H. Williams, J. Fournelle, K.C. Wrighton, K.M. Handley, J.F. Banfield, Vanadate and acetate biostimulation of contaminated sediments decreases diversity, selects for specific taxa, and decreases aqueous $\mathrm{V}^{5+}$ concentration, Environ. Sci. Technol. 47 (2013) 6500-6509.

[10]A. Bhatnagar, A.K. Minocha, D. Pudasainee, H.K. Chung, S.H. Kim, H.S. Kim, G. Lee, B. Min, B.H. Jeon, Vanadium removal from water by waste metal sludge and cement immobilization, Chem. Eng. J. 144 (2008) 197-204.

[11]J. Zhang, H.L. Dong, L.D. Zhao, R. McCarrick, A. Agrawal, Microbial reduction and precipitation of vanadium by mesophilic and thermophilic methanogens, Chem. Geol. 370 (2014) 29-39.

[12]B.G. Zhang, C.P. Feng, J.R. Ni, J. Zhang, W.L. Huang, Simultaneous reduction of vanadium (V) and chromium (VI) with enhanced energy recovery based on microbial fuel cell technology, J. Power Sources 204 (2012) 34-39.

[13]L.T. Hao, B.G. Zhang, M. Cheng, C.P. Feng, Effects of various organic carbon 
sources on simultaneous $\mathrm{V}(\mathrm{V})$ reduction and bioelectricity generation in single chamber microbial fuel cells, Bioresour. Technol. 201 (2016) 105-110.

[14]C.F. Yang, C.M. Lee, Pentachlorophenol contaminated groundwater bioremediation using immobilized Sphingomonas cells inoculation in the bioreactor system, J. Hazard. Mater. 152 (2008) 159-165.

[15]H. Li, S. Chen, L.Y. Ren, L.Y. Zhou, X.J. Tan, Y. Zhu, C. Belver, J. Bedia, J. Yang, Biochar mediates activation of aged nanoscale ZVI by Shewanella putrefaciens CN32 to enhance the degradation of Pentachlorophenol. Chem. Eng. J. 368, (2019) 148-156.

[16]X. Zhao, W. Tan, Q. Dang, R. Li, B. Xi, Enhanced biotic contributions to the dechlorination of pentachlorophenol by humus respiration from different compostable environments, Chem. Eng. J. 361 (2019) 1565-1575.

[17]A. Mikkonen, K. Yläranta, M. Tiirola, L.A.L. Dutra, P. Salmi, M. Romantschuk, S. Copley, J. Ikäheimo, A. Sinkkonen, Successful aerobic bioremediation of groundwater contaminated with higher chlorinated phenols by indigenous degrader bacteria, Water Res. 138 (2018) 118-128.

[18]J.H. Langwaldt, M.K. Männistö, R. Wichmann, J.A. Puhakka, Simulation of in-situ subsurface biodegradation of polychlorophenols in air-lift percolators, Appl. Microbiol. Biotechnol. 49 (1998) 663-668.

[19]H.L. Lien, Y.S. Jhuo, L.H. Chen, Effect of heavy metals on dechlorination of carbon tetrachloride by iron nanoparticles, Environ. Eng. Sci. 24 (2007) 21-30.

[20] S.M. Shaheen, J. Rinklebe, Vanadium in thirteen different soil profiles 
originating from Germany and Egypt: Geochemical fractionation and potential mobilization, Appl. Geochem. 88 (2017) 288-301.

[21]M. Zhu, L.J. Zhang, L.W. Zheng, Y. Zhuo, J.M. Xu, Y. He, Typical soil redox processes in pentachlorophenol polluted soil following biochar addition, Front. Microbiol. 9 (2018) 579.

[22]X. Zhao, W. Tan, Q. Dang, R. Li, B. Xi, Enhanced biotic contributions to the dechlorination of pentachlorophenol by humus respiration from different compostable environments, Chem. Eng. J. 361 (2019) 1565-1575.

[23]B.G. Zhang, H.Z. Zhao, C.H. Shi, S.G. Zhou, J.R. Ni, Simultaneous removal of sulfide and organics with vanadium(V) reduction in microbial fuel cells, J. Chem. Tech. Biotech. 84 (2009) 1780-1786.

[24]L.T. Hao, B.G. Zhang, C.X. Tian, Y. Liu, C.H. Shi, M. Cheng, C.P. Feng, Enhanced microbial reduction of vanadium (V) in groundwater with bioelectricity from microbial fuel cells, J. Power Sources 287 (2015) 43-49.

[25]H. Tong, C.S. Liu, F.B. Li, C.L. Luo, M.J. Chen, M. Hu, The key microorganisms for anaerobic degradation of pentachlorophenol in paddy soil as revealed by stable isotope probing, J. Hazard. Mater. 298 (2015) 252-260.

[26] W. Carpentier, L.D. Smet, J.V. Beeumen, A. Brigé, Respiration and growth of Shewanella oneidensis MR-1 using vanadate as the sole electron acceptor, J. Bacteriol. 187 (2005) 3293-3301.

[27]G.Y. Wang, B.G. Zhang, S. Li, M. Yang, C.C. Yin, Simultaneous microbial reduction of vanadium (V) and chromium (VI) by Shewanella loihica PV-4. 
Bioresour. Technol. 227 (2017) 353-358.

[28] Y. Xu, Y. He, X. Feng, L. Liang, J. Xu, P.C. Brookes, J. Wu, Enhanced abiotic and biotic contributions to dechlorination of pentachlorophenol during Fe (III) reduction by an iron-reducing bacterium Clostridium beijerinckii Z, Sci. Total Environ. 473 (2014) 215-223.

[29] L. Bosso, G. Cristinzio, A comprehensive overview of bacteria and fungi used for pentachlorophenol biodegradation, Rev. Environ. Sci. Biotechnol. 13 (2014) $387-427$.

[30]H.Y. Yu, Y.K. Wang, P.C. Chen, F.B. Li, M.J. Chen, M. Hu, X.G. Ouyang, Effect of nitrate addition on reductive transformation of pentachlorophenol in paddy soil in relation to iron(III) reduction, J. Environ Manage. 132 (2014) 42-48.

[31]L.L. Xue, X. Feng, Y. Xu, X.F. Li, M. Zhu, J.M. Xu, Y. He, The dechlorination of pentachlorophenol under a sulfate and iron reduction cooccurring anaerobic environment, Chemosphere 182 (2017) 166-173.

[32]M. Long, Z.E. Ilhan, S. Xia, C. Zhou, B.E. Rittmann, Complete dechlorination and mineralization of pentachlorophenol (PCP) in a hydrogen-based membrane biofilm reactor (MBfR), Water Res. 144 (2018) 134-144.

[33] G.J. Wilson, A.P. Khodadoust, M.T. Suidan, R.C. Brenner, C.M. Acheson, Anaerobic/aerobic biodegradation of pentachlorophenol using GAC fluidized bed reactors: Optimization of the empty bed contact time, Water Sci.Technol. 38 (1998) 9-17.

[34]L.L. Xue, X. Feng, Y. Xu, X.F. Li, M. Zhu, J.M. Xu, Y. He, The dechlorination of 
pentachlorophenol under a sulfate and iron reduction cooccurring anaerobic environment, Chemosphere 182 (2017) 166-173.

[35]M. Chen, K. Shih, M. Hu, F. Li, C. Liu, W. Wu, H. Tong, Biostimulation of indigenous microbial communities for anaerobic transformation of pentachlorophenol in paddy soils of southern China, J. Agric. Food Chem. 60 (2012) 2967-2975.

[36]J. Shi, B. Zhang, R. Qiu, C. Lai, Y. Jiang, C. He, J. Guo, Microbial chromate reduction coupled to anaerobic oxidation of elemental sulfur or zerovalent iron, Environ. Sci. Technol. 53, (2019) 3198-3207.

[37]C.Y. Lai, Q.Y. Dong, J.X. Chen, Q.S. Zhu, X. Yang, W.D. Chen, H.P. Zhao, L. $\mathrm{Zhu}$, Role of extracellular polymeric substances in a methane based membrane biofilm reactor reducing vanadate, Environ. Sci. Technol. 52 (2018), 10680-10688.

[38]H.L. Wang, G.D. Ji, X.Y. Bai, C.G. He, Assessing nitrogen transformation processes in a trickling filter under hydraulic loading rate constraints using nitrogen functional gene abundances, Bioresour. Technol. 177 (2015) 217-223.

[39]Z.L. Li, J. Nan, J.Q. Yang, X. Jin, A. Katayama, A.J. Wang, Temporal distributions of functional microbes and putative genes associated with halogenated phenol anaerobic dehalogenation and further mineralization, RSC Adv. 5 (2015) 89157-89163.

[40] Y.C. Zhao, H.S. Hsieh, M. Wang, C.T. Jafvert, Light-independent redox reactions of graphene oxide in water: Electron transfer from NADH through graphene 
oxide to molecular oxygen, producing reactive oxygen species, Carbon 123 (2017) 216-222.

[41]D. Kang, Q.J. Lin, D.D. Xu, Q.Y. Hu, Y.Y. Li, A.Q. Ding, M. Zhang, P. Zheng, Color characterization of anammox granular sludge: Chromogenic substance, microbial succession and state indication, Sc. Total Environ. 642 (2018) $1320-1327$.

[42]H. Liu, B.G. Zhang, Y. Xing, L.T. Hao, Behavior of dissolved organic carbon sources on the microbial reduction and precipitation of vanadium(V) in groundwater, RSC Adv. 6 (2016) 97253-97258.

[43]H. Tong, M. Hu, F.B. Li, M.J. Chen, Y.H. Lv, Burkholderiales participating in pentachlorophenol biodegradation in iron-reducing paddy soil as identified by stable isotope probing, Environ. Sci. Proc. Impacts 17 (2015) 1282-1289.

[44]J.G. Mueller, D.P. Middaugh, S.E. Lantz, P.J. Chapman, Biodegradation of creosote and pentachlorophenol in contaminated groundwater: chemical and biological assessment, Appl. Environ. Microbiol. (1991) 1277-1285.

[45]R. Meng, T. Chen, Y. Zhang, W. Lu, Y. Liu, T. Lu, Y. Liu, H. Wang, Development, modification, and application of low-cost and available biochar derived from corn straw for the removal of vanadium(V) from aqueous solution and real contaminated groundwater. RSC Adv. 8 (2018) 21480-21494.

[46]F.B. Li, X.G. Wang, Y.T. Li, C.S. Liu, F. Zeng, L.J. Zhang, M.D. Hao, H.D. Ruan, Enhancement of the reductive transformation of pentachlorophenol by polycarboxylic acids at the iron oxide-water interface, J. Colloid Interf. Sci. 321 
(2008) 332-341.

[47]M.D. Khan, N. Khan, A.S. Nizami, M. Rehan, S. Sabir, M.Z. Khan, Effect of co-substrates on biogas production and anaerobic decomposition of pentachlorophenol, Bioresour. Technol. 238 (2017) 492-501.

[48] B.G. Zhang, S.Q. Zou, R.Q. Cai, M. Li, Z. He, Highly-efficient Photocatalytic disinfection of Escherichia coli under visible light using carbon supported vanadium tetrasulfide nanocomposites, Appl. Catal. B Environ. 224 (2018) 383-393.

[49]R.Q. Cai, B.G. Zhang, J.X. Shi, M. Li, Z. He, Rapid photocatalytic decolorization of methyl orange under visible light using $\mathrm{VS}_{4} /$ carbon powder nanocomposites, ACS Sustain. Chem. Eng. 5 (2017) 7690-7699.

[50]R. Qiu, B.G. Zhang, J.X. Li, Q. Lv, S. Wang, Q. Gu, Enhanced vanadium (V) reduction and bioelectricity generation in microbial fuel cells with biocathode, J. Power Sources 359 (2017) 379-383.

[51]L.P. Yu, Y. Yuan, J. Tang, Y.Q. Wang, S.G. Zhou, Biochar as an electron shuttle for reductive dechlorination of pentachlorophenol by Geobacter sulfurreducens, Sci. Rep. 5 (2015) 16221-16231.

[52]R.A. Freeborn, K.A.West, V.K. Bhupathiraju, S. Chauhan, B.G. Rahm, R.E. Richardson, L. Alvarez-Cohen, Phylogenetic analysis of TCE-dechlorinating consortia enriched on a variety of electron donors, Environ. Sci. Technol. 39 (2005) 8358-8368.

[53]B. Jugder, H. Ertan, M. Lee, M. Manefield, C.P. Marquis, Reductive 
dehalogenases come of age in biological destruction of organohalides, Trends Biotechnol. 33 (2015) 595-610.

[54] A.D. Fricker, S.L. LaRoe, M.E. Shea, D.L. Bedard, Dehalococcoides mccartyi strain JNA dechlorinates multiple chlorinated phenols including pentachlorophenol and harbors at least 19 reductive dehalogenase homologous genes, Environ. Sci. Technol. 48 (2014) 14300-14308.

[55]E. Ferrer-Polonio, N.T. García-Quijano, J.A. Mendoza-Roca, A. Iborra-Clar, L. Pastor-Alcañiz, Effect of alternating anaerobic and aerobic phases on the performance of a SBR treating effluents with high salinity and phenols concentration, Biochem. Eng. J. 113 (2016) 57-65.

[56] G.M. Zeng, Z. Yu, Y.N. Chen, J.C. Zhang, H. Li, M. Yu, M.J. Zhao, Response of compost maturity and microbial community composition to pentachlorophenol (PCP)-contaminated soil during composting. Bioresour. Technol. 102 (2011) 5905-5911.

[57]B.G. Zhang, L.T. Hao, C.X. Tian, S.H. Yuan, C.P. Feng, J.R. Ni, A.G.L. Borthwick, Microbial reduction and precipitation of vanadium (V) in groundwater by immobilized mixed anaerobic culture, Bioresour. Technol. 192 (2015) 410-417.

[58] S. Wang, B.G. Zhang, M.H. Diao, J.X. Shi, Y.F. Jiang, Y.T. Cheng, H. Liu, Enhancement of synchronous bio-reductions of vanadium (V) and chromium (VI) by mixed anaerobic culture, Environ. Pollut. 242 (2018) 249-256.

[59] S.M.J. Mirazimi, Z. Abbasalipour, F. Rashchi, Vanadium removal from LD 
converter slag using bacteria and fungi, J. Environ. Manage. 153 (2015) 144-151.

[60]R. Chug, V.S. Gour, S. Mathur, S.L. Kothari, Optimization of extracellular polymeric substances production using Azotobacter beijreinckii and Bacillus subtilis and its application in chromium (VI) removal, Bioresour. Technol. 214 (2016) 604-608.

[61] Y. Yu, Y. Wu, B. Cao, Y.G. Gao, X. Yan, Adjustable bidirectional extracellular electron transfer between Comamonas testosteroni biofilms and electrode via distinct electron mediators, Electrochem. Commun. 59 (2015) 43-47.

[62]K.C. Wrighton, B. Virdis, P. Clauwaert, S.T. Read, R.A. Daly, N. Boon, Y. Piceno, G.L. Andersen, J.D. Coates, K. Rabaey, Bacterial community structure corresponds to performance during cathodic nitrate reduction, ISME J. 4 (2010) 1443-1455.

[63]F. Aulenta, S. Rossetti, S. Amalfitano, M. Majone, V. Tandoi, Conductive magnetite nanoparticles accelerate the microbial reductive dechlorination of trichloroethene by promoting interspecies electron transfer processes, ChemSusChem 6 (2013) 433-436.

[64]Z.L. Li, Y. Inoue, S.Y. Yang, N. Yoshida, A. Katayama, Mass balance and kinetic analysis of anaerobic microbial dechlorination of pentachlorophenol in a continuous flow column, J. Biosci. Bioeng. 10 (2010) 326-332.

[65] S.S. Adav, M.Y. Chen, D.J. Lee, N.Q. Ren, Degradation of phenol by Acinetobacter strain isolated from aerobic granules, Chemosphere 67 (2007) 1566-1572. 
[66]A. Nowak, A. Mrozik, Degradation of 4-chlorophenol and microbial diversity in soil inoculated with single Pseudomonas sp. CF600 and Stenotrophomonas maltophilia KB2, J. Environ. Manage. 215 (2018) 216-229.

[67] S.N. Parshina, R. Kleerebezem, J.L. Sanz, G. Lettinga, A.N. Nozhevnikova, N.A. Kostrikina, A.M. Lysenko, A.J.M. Stams, Soehngenia saccharolytica gen. nov., sp. nov. and Clostridium amygdalinum sp. nov., two novel anaerobic, benzaldehyde-converting bacteria, Int. J. Syst. Evol. Micr. 53 (2003) 1791-1799.

[68] Y. Miura, A.Y. Watanabe, S. Okabe, Significance of Chloroflexi in performance of submerged membrane bioreactors (MBR) treating municipal wastewater, Environ. Sci. Technol. 4 (2007) 7787-7794.

[69]X.Y. Xu, S.Q. Xia, L.J. Zhou, Z.Q. Zhang, B.E. Rittmann, Bioreduction of vanadium (V) in groundwater by autohydrogentrophic bacteria: Mechanisms and microorganisms, J. Environ. Sci. 30 (2015) 122-128.

[70] Y. Nangia, N. Wangoo, N. Goyal, G. Shekhawat, C.R. Suri, A novel bacterial isolate Stenotrophomonas maltophilia as living factory for synthesis of gold nanoparticles, Microb. Cell Fact. 8 (2009) 39.

[71]C.D. Della Torre, R. Zaja, J. Loncar, T. Smital, S. Focardi, I. Corsi, Interaction of $\mathrm{ABC}$ transport proteins with toxic metals at the level of gene and transport activity in the PLHC-1 fish cell line, Chem. Biol. Interact. 198 (2012) 9-17.

[72] Y.Z. Lu, G.J. Chen, Y.N. Bai, L. Fu, L.P. Qin, R.J. Zeng, Chromium isotope fractionation during $\mathrm{Cr}(\mathrm{VI})$ reduction in a methane-based hollow-fiber membrane biofilm reactor, Water Res. 130 (2018) 263-270. 
[73]X. Lu, W.D. Johnson, J. Hook, Reaction of vanadate with aquatic humic substances: An ESR and 51V NMR study, Environ. Sci. Technol. 32 (1998) $2257-2263$.

[74]P. D’Abzac, F. Bordas, E.V. Hullebusch, P.N.L. Lens, G. Guibaud, Extraction of extracellular polymeric substances (EPS) from anaerobic granular sludges: comparison of chemical and physical extraction protocols, Appl. Microbiol. Biotech. 85 (2010) 1589-1599.

[75] W.J. Wang, W.H. Wang, X.L. Zhang, D.H. Wang, Adsorption of p-chlorophenol by biofilm components, Water Res. 36 (2002) 551-560.

[76]J. Renpenning, I. Rapp, I. Nijenhuis, Substrate hydrophobicity and cell composition influence the extent of rate limitation and masking of isotope fractionation during microbial reductive dehalogenation of chlorinated ethenes, Environ. Sci. Technol. 49 (2015) 4293-4301.

[77]P. Devi, A.K. Saroha, Simultaneous adsorption and dechlorination of pentachlorophenol from effluent by Ni-ZVI magnetic biochar composites synthesized from paper mill sludge, Chem. Eng. J. 271, (2015) 195-203.

[78]R. Sauleda, E. Brillas, Mineralization of aniline and 4-chlorophenol in acidic solution by ozonation catalyzed with $\mathrm{Fe}^{2+}$ and UVA light, Appl. Catal. B Environm. 29 (2001) 135-145.

[79]M.Á. Arellano-González, I. González, A.C. Texier, Mineralization of 2-chlorophenol by sequential electrochemical reductive dechlorination and biological processes, J. Hazard. Mater. 314 (2016) 181-187. 


\section{Figure captions.}

Fig. 1. Time histories of V(V) and PCP concentrations over three consecutive operation cycles in different bioreactors. Blue arrows indicate replacement of synthetic groundwater.

Fig. 2. Characterization of reaction products and solution conditions during V(V) and PCP bio-reductions in B-P/V in a typical operation cycle $(7 \mathrm{~d})$. (a) change in dissolved total V with time; (b) XPS analysis of the collected precipitates; (c) variation in PCP reductive dechlorination products with time; and (d) changes in TOC and $\mathrm{pH}$ with time.

Fig. 3. Influence of key operation parameters on V(V) and PCP removals in a typical cycle (7 d) in B-P/V. Effect of initial V(V) concentration on removals of (a) V(V), and (b) PCP; and impact of initial ethanol dosage on removals of (c) V(V), and (d) PCP.

Fig. 4. Microbial community structures of inocula and bioreactors revealed by Illumina sequencing at: (a) phylum level; and (b) genus level.

Fig. 5. Quantification of functional genes and pertinent enzymes possibly involved in $\mathrm{V}(\mathrm{V})$ and PCP bio-reductions in all bioreactors. (a) functional genes; (b) pertinent enzymes.

Fig. 6. Contents and characteristics of EPS in inocula and bioreactors: (a) concentrations of PN, PS, and HS components in EPS; and (b) FTIR spectra.

Fig. 7. Schematic representation of possible mechanisms involved in V(V) reduction and $\mathrm{PCP}$ reductive dechlorination in $\mathrm{B}-\mathrm{V} / \mathrm{P}$. 


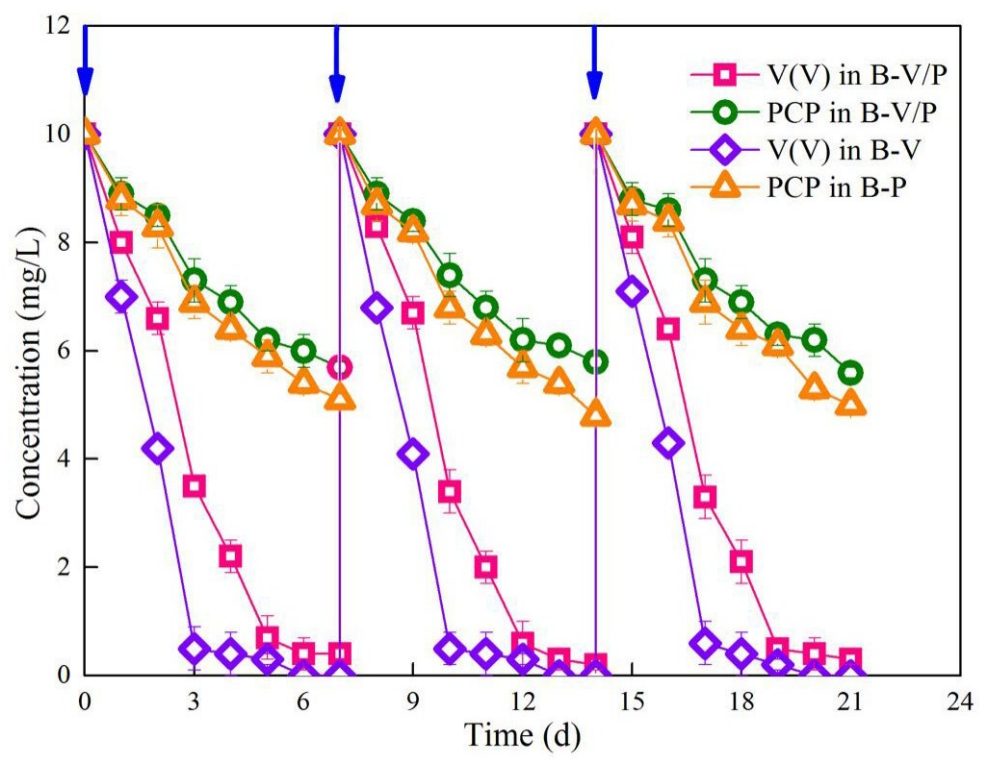

Fig. 1. Time histories of $\mathrm{V}(\mathrm{V})$ and $\mathrm{PCP}$ concentrations over three consecutive operation cycles in different bioreactors. Blue arrows indicate replacement of synthetic groundwater. 

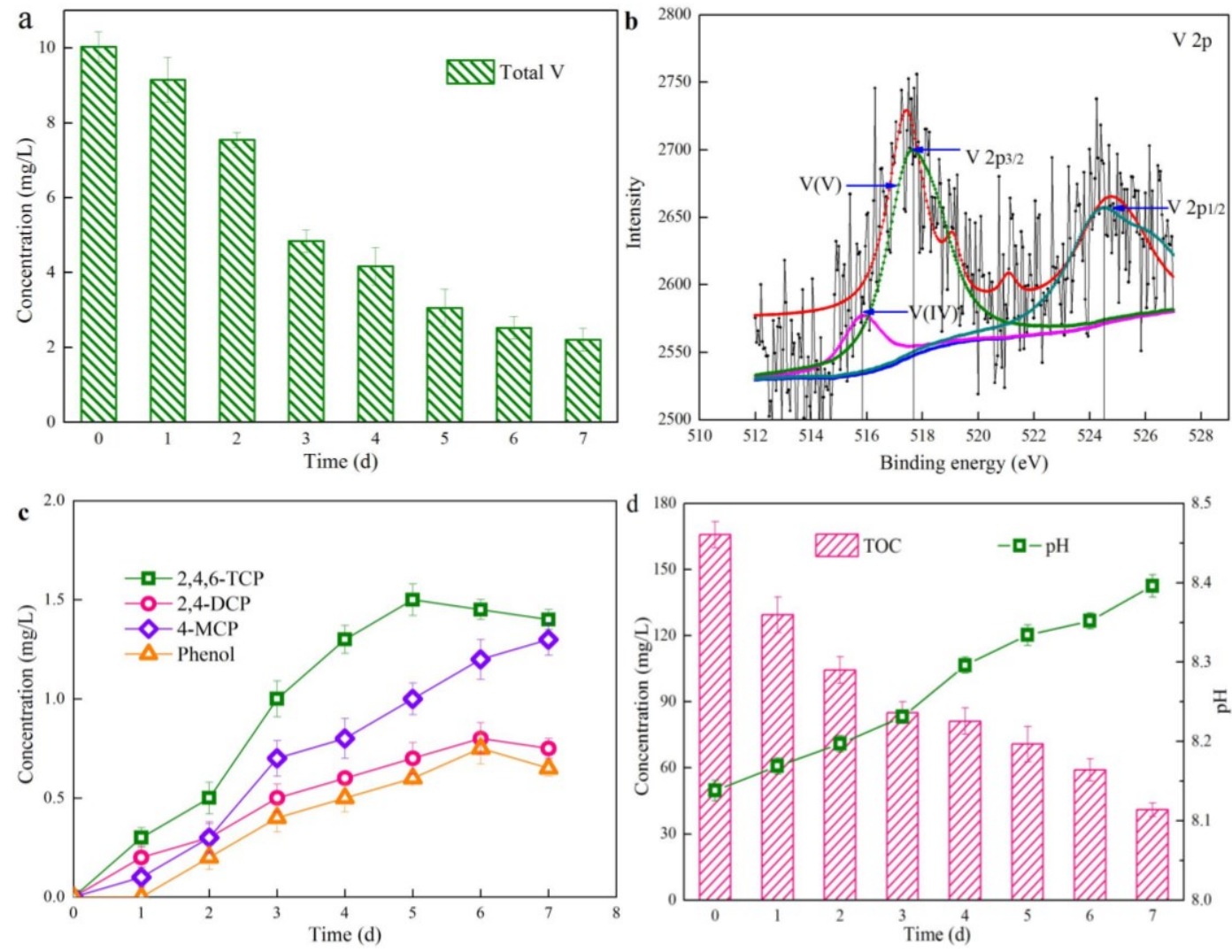

Fig. 2. Characterization of reaction products and solution conditions during V(V) and PCP bio-reductions in B-P/V in a typical operation cycle (7 d). (a) change in dissolved total V with time; (b) XPS analysis of the collected precipitates; (c) variation in PCP reductive dechlorination products with time; and (d) changes in TOC and $\mathrm{pH}$ with time. 

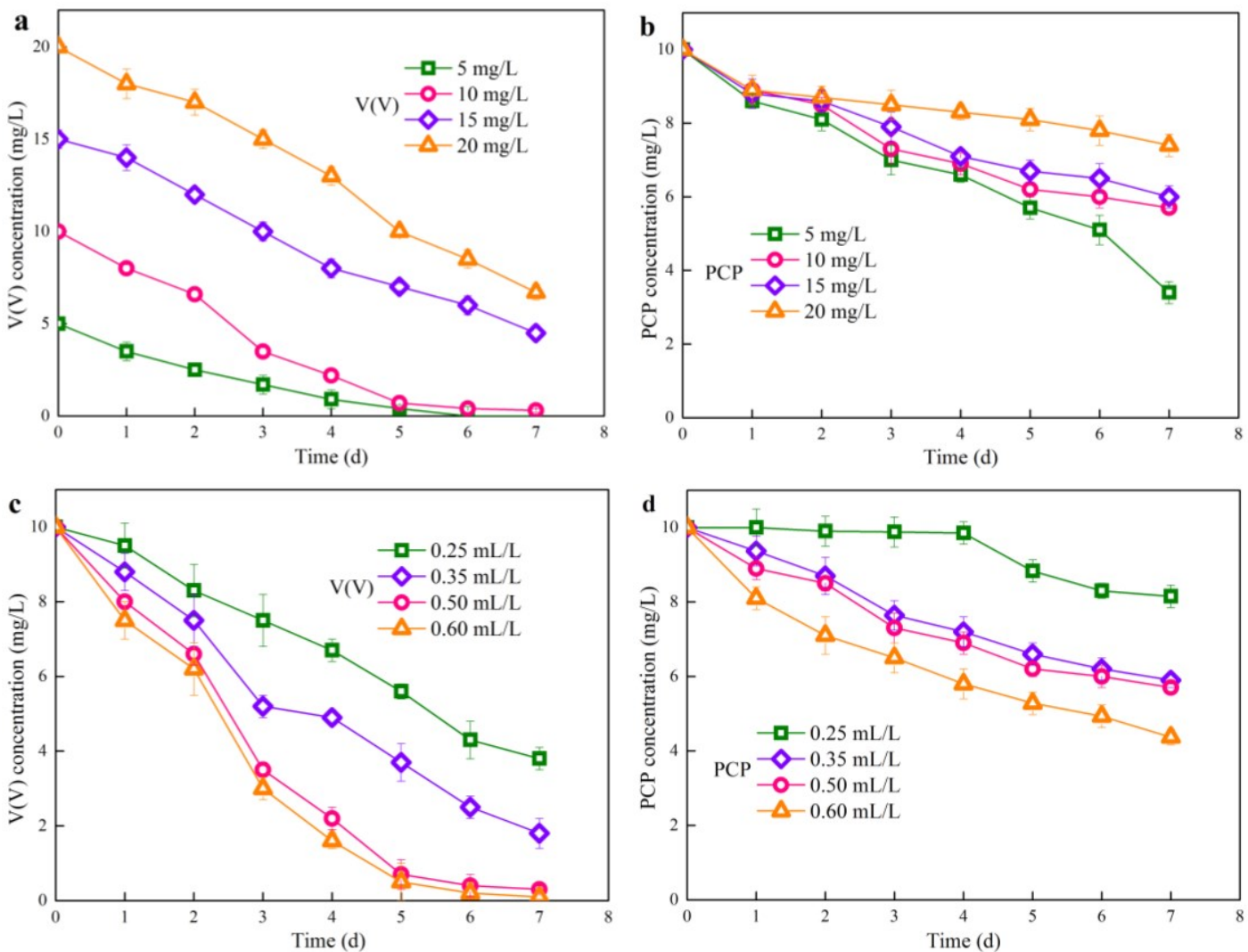

Fig. 3. Influence of key operation parameters on V(V) and PCP removals in a typical cycle (7 d) in B-P/V. Effect of initial V(V) concentration on removals of (a) V(V), and (b) PCP; and impact of initial ethanol dosage on removals of (c) V(V), and (d) PCP. 

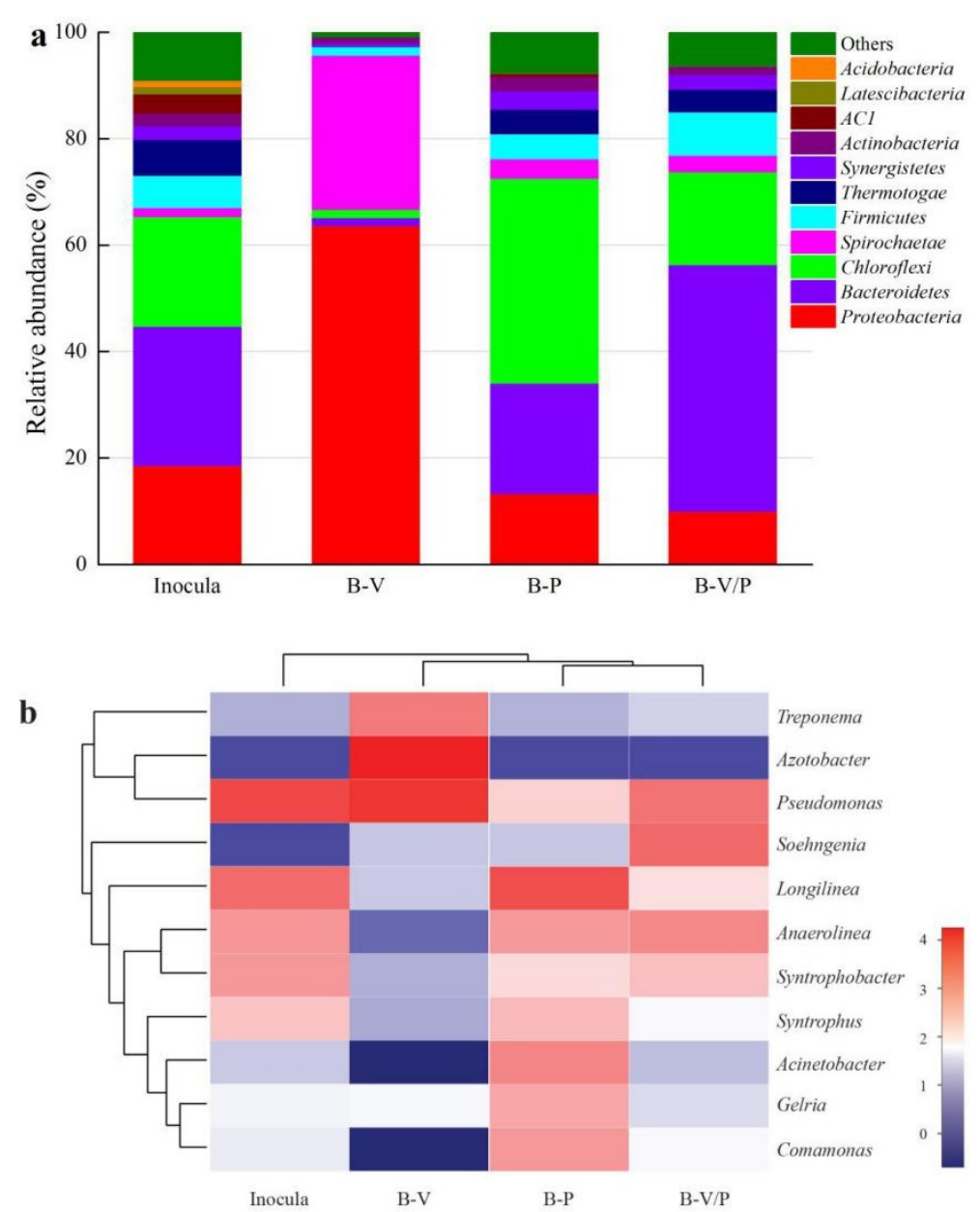

Fig. 4. Microbial community structures of inocula and bioreactors revealed by

Illumina sequencing at: (a) phylum level; and (b) genus level. 

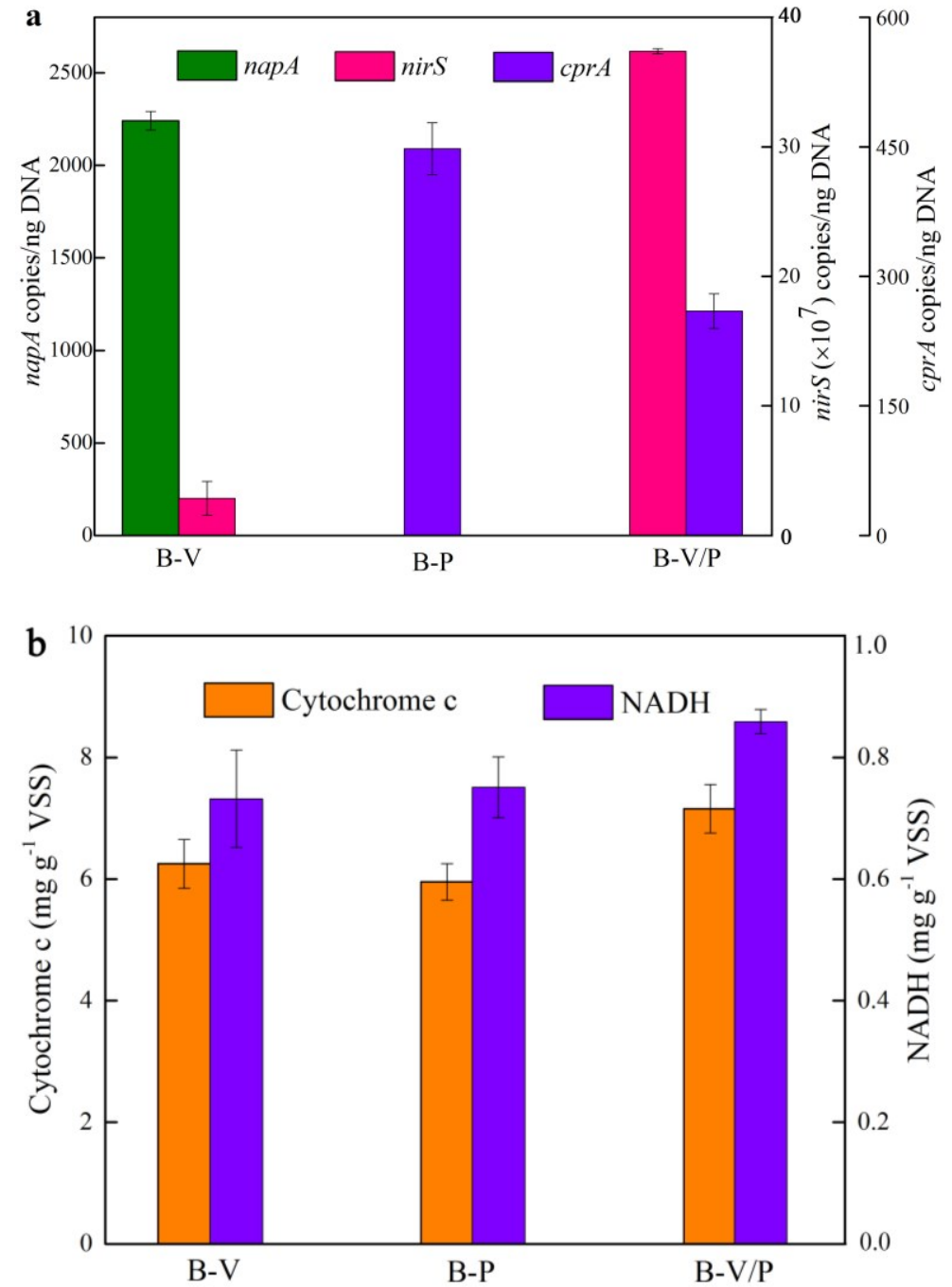

Fig. 5. Quantification of functional genes and pertinent enzymes possibly involved in $\mathrm{V}(\mathrm{V})$ and PCP bio-reductions in all bioreactors. (a) functional genes; (b) pertinent enzymes. 

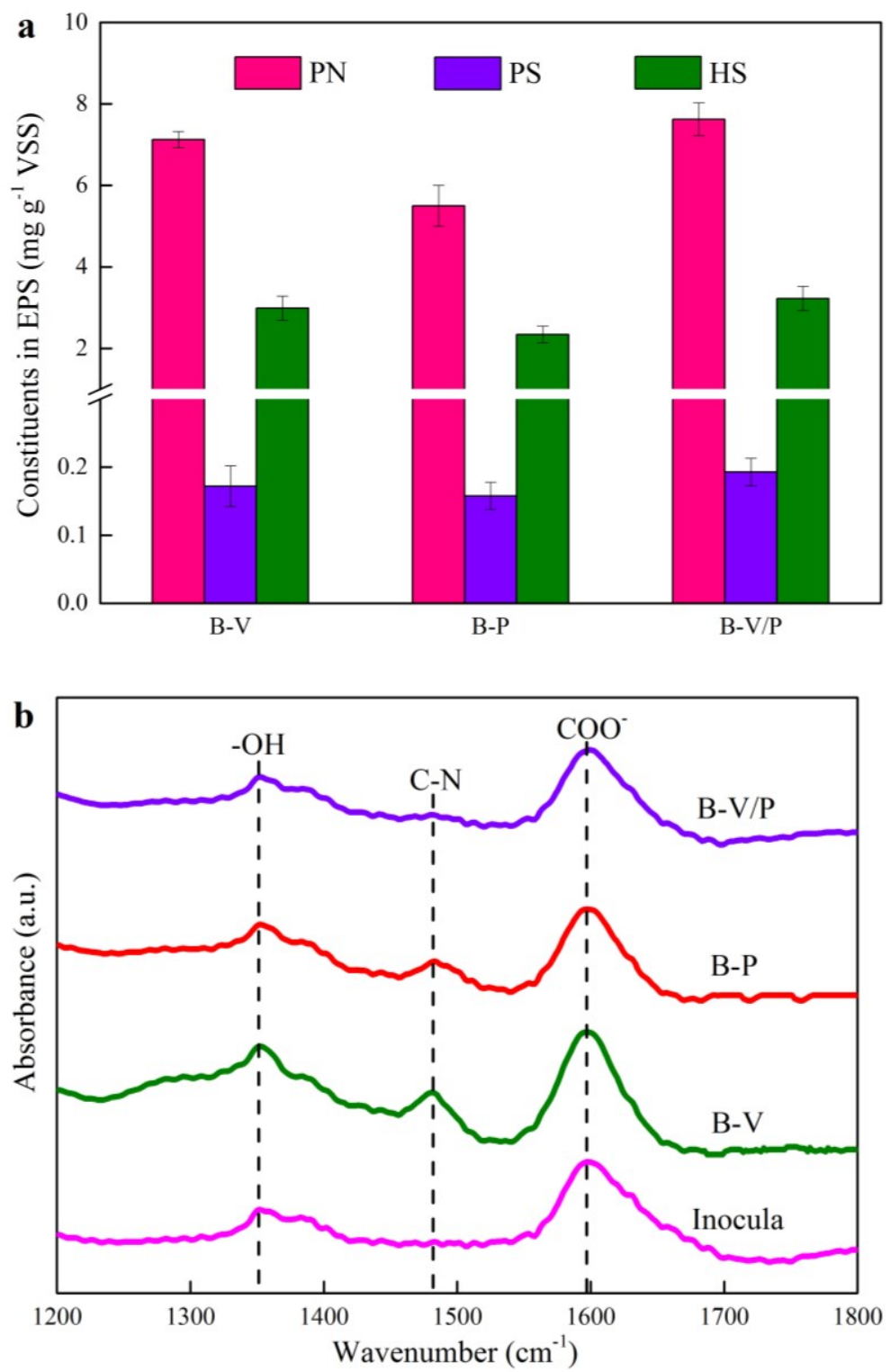

Fig. 6. Contents and characteristics of EPS in inocula and bioreactors: (a) concentrations of PN, PS, and HS components in EPS; and (b) FTIR spectra. 


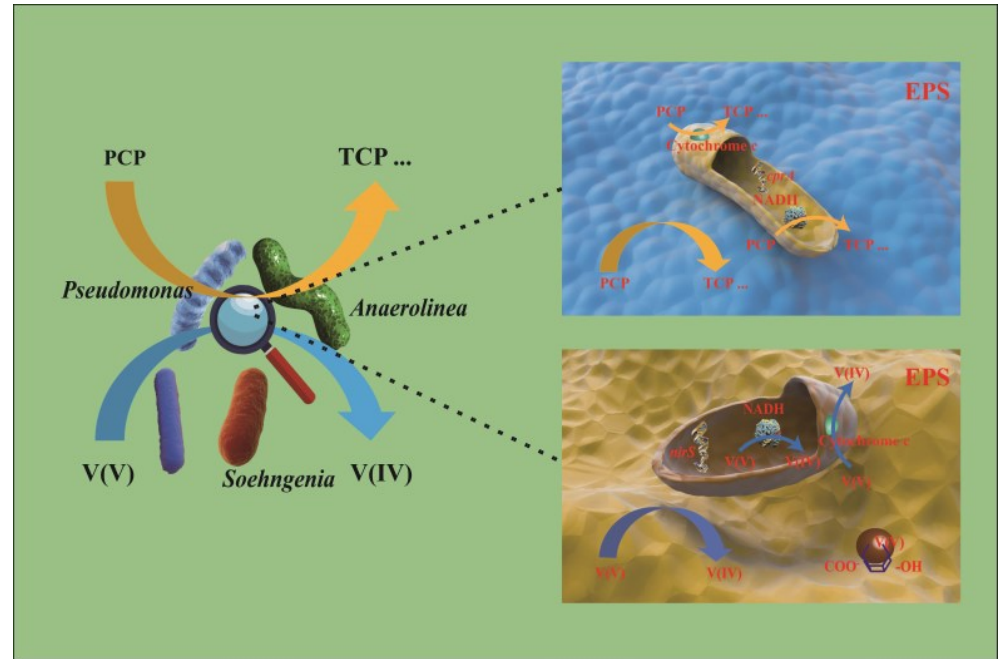

Fig. 7. Schematic representation of possible mechanisms involved in V(V) reduction and $\mathrm{PCP}$ reductive dechlorination in $\mathrm{B}-\mathrm{V} / \mathrm{P}$. 